\title{
PENGARUH PANJANG DAN KESEJAJARAN ANTARA LANTAI INJAK DENGAN LANTAI JEMBATAN DI AWAL BENTANG TERHADAP TINGKAT KERUSAKAN LANTAI JEMBATAN
}

\author{
Andi Indianto ${ }^{1}$ dan Setiyadi \\ ${ }^{1}$ Lektor Kepala pada PS. PJJ. Jurusan Teknik Sipil PNJ. Kampus UI depok 16424, 08129293266 \\ Email: andipoltek@gmail.com
}

\begin{abstract}
This research presenting the influence of the length and extent of the approach floor on the oprit against damage to the bridge deck. This research is done because most of the damage to the bridge deck occurred at the beginning of the span.The purpose of this research is to know how big influence of length and alignment of approach floor to damage of bridge floor at beginning of span.To achieve the above purpose,conducted research against 18 bridges in Depok and Cibinong. With sampling in the form of long approach floor, alignment of the floor stepped on the bridge deck at the beginning of the span, observation of bridge deck damage and width measurement cracked the bridge deck at the beginning of the span. After the data has been collected, the next step is to analyze the effect of floor length and alignment on the bridge deck damage. The results show that length and alignment approach floor with a bridge deck the beginning of the span is very influential on damage to the bridge deck at the beginning of the span, with a confidence level of 0.77 . The bigger the slope difference of the approach floor with the slope of the bridge deck at the beginning of the span, and getting shorter approach floor damage to the bridge deck at the beginning of the span is getting bigger.
\end{abstract}

Keywords: Approach floor, bridge deck.

\section{PENDAHULUAN}

\subsection{Latar Belakang}

Lantai Jembatan adalah salah satu elemen penting dari struktur jembatan yang berperan langsung menerima beban lalu lintas. Oleh karena itu lantai jembatan tidak boleh mengalami kerusakan. Lantai jembatan harus dihindarkan dari pengaruh beban tumbukan atau momentum dari kendaraan yang melewatinya. Untuk menjaga agar lantai jembatan tidak menerima beban tumbukan dari roda kendaraan, maka jalan pendekat menuju jembatan, permukaannya harus dibuat rata, panjangnya tidak kurang dari jarak antar as roda kendaraan, dan permukaannya harus sejajar terhadap lantai jembatan diawal bentang. Bertitik tolak dari latar belakang diatas, maka penulis ber asumsi bahwa kerusakan lantai jembatan diawal bentang diakibatkan oleh adanya jalan pendekat yang tidak dapat menghantarkan laju kendaraan dengan sempurna, sehingga menimbulkan kejutan atau momentum pada lantai jembatan.

\subsection{Masalah}

Munculnya kerusakan lantai jembatan sering terjadi di awal bentang

\subsection{Tujuan}

Untuk mendiskripsikan penyebab kerusakan lantai jembatan diawal bentang , dan untuk membuktikan asumsi apakah benar panjang dan kelandaianan lantai injak mempengaruhi tingkat kerusakan lantai jembatan diawal bentang.

\section{Bahan Kajian}

2.1 Lantai Jembatan

Lantai jembatan adalah bagian dari jembatan yang langsung menerima beban lalu lintas kendaraan dan pejalan kaki.

\subsection{Lantai Injak}

Lantai injak adalah bagian dari oprit yang berfungsi mentransfer beban lalu lintas dari jalan menuju jembatan. Lantai injak dibuat dengan tujuan agar tidak terjadi momentum pada lantai jembatan diawal bentang. Panjang lantai injak tidak boleh kurang dari 5 meter (perencanaan teknik 
jembatan hal.8), dan permukan lantai injak harus dibuat sejajar dengan permukaan lantai jembatan diawal bentang.
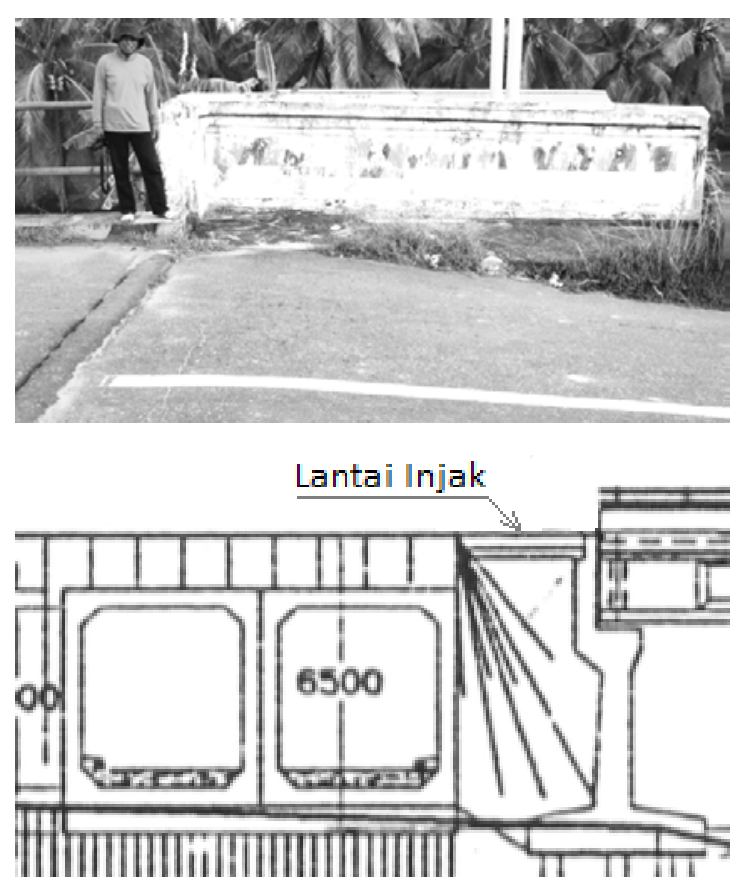

Gambar 1. Lantai injak pada oprit

2.3 Kerusakan retak dan Rembesan atau bocoran pada lantai jembatan

Retak struktur adalah retak yang paling berbahaya. Retak ini diakibatkan adanya beban yang berlebih atau kekuatan dari beton tidak memadai. Retak struktur disebabkan oleh :

- Momen lentur. Retak ini berupa retak arah melintang di tengah bentang

- Gaya lintang. Retak ini terjadi di dekat tumpuan, retak ini disebut retak geser.

- Retak akibat kombinasi momen dan lintang. Retak ini disebut retak geser lentur.

Batas layan retak maksimum 0,2 mm.( Panduan Penanganan Preservasi Jembatan hal. 42)

Rembesan air atau bocoran dalam beton terjadi akibat retak yang tembus dari bawah ke atas. Rembesan dapat dikenali dengan adanya tanda tanda sebagai berikut:

- Adanya daerah yang basah terus menerus.

- Warna hijau karena ditumbuhi lumut.
- Warna putih berkerak atau bahkan membentuk stalaktit berwarna putih, ini terjadi karena larutan kapur pada semen merembes keluar.

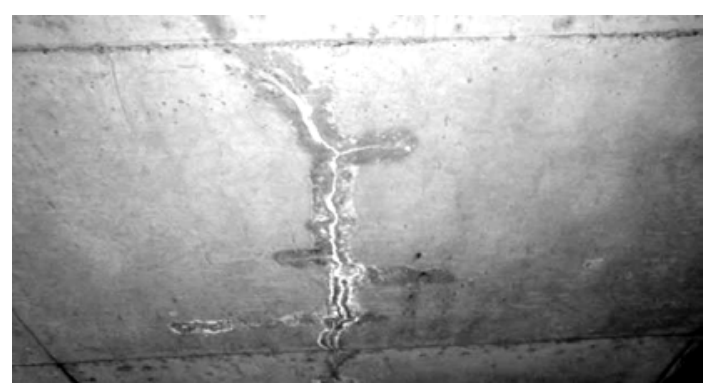

Gambar 3. Rembesan pada beton yang retak

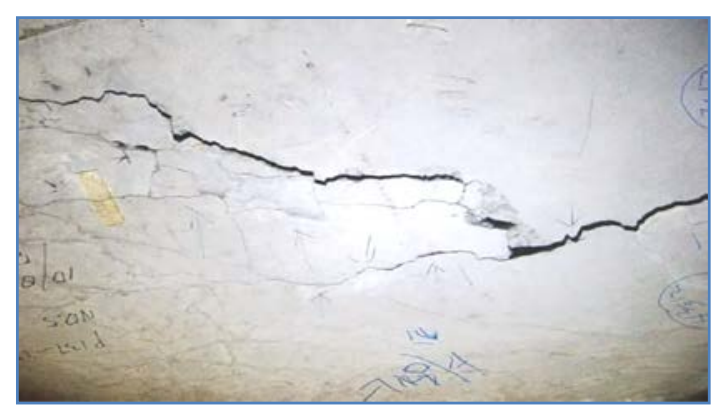

Gambar 4. Retak Struktur

\section{METODA PENELITIAN}

3.1 Metode Pengumpulan Data

Pengumpulan data dilakukan dengan pengamatan dan pengukuran langsung terhadap oprit dan lantai jembatan di awal bentang. Penentuan sempel dilakukan secara acak dan dengan memilih kondisi oprit yang terkait dengan kerataan permukaan oprit, Pengamatan dilakukan terhadap Pola / jenis keretakan / kerusakan lantai jembatan diawal bentang. Sedangkan pengukuran dilakukan terhadap:panjang lantai injak, kesejajaran lantai injak terhadap permukaan lantai jembatan, dan pengukuran lebar retak lantai jembatan diawal bentang.

Alat alat yang digunakan untuk mengumpulkan data adalah:

a. Laser meter dan meteran, digunakan untuk mengukur panjang lantai injak.

b. waterpass digital, digunakan untuk mengukur kemiringan arah memanjang jembatan pada lantai jembatan diawal bentang dan 
kemiringan arah memanjang jembatan pada lantai injak .

c. Sigmat digital, digunakan untuk pengukuran lebar retak pada lantai jembatan.

\subsection{Metode Penyajian Data}

Penyajian data dilakukan dengan mentabulasikan semua data hasil pengukuran. Data tersebut adalah panjang oprit, kesejajaran oprit terhadap lantai jembatan dan lebar retak yang terjadi pada lantai jembatan diawal bentang.

\subsection{Metode Analisa Data}

Untuk analisa data digunakan variabel bebas (X) yaitu kemiringan oprit, dan panjang oprit, dan variabel terikat $(\mathrm{Y})$ adalah lebar retak pada lantai jembatan . Untuk mencari pengaruh kondisi oprit terhadap kerusakan lantai jembatan diawal bentang digunakan regresi linier. Kurva yang disajikan merupakan hasil olahan dari dua faktor yang dihubungkan, yaitu kurva hubungan antara retak lantai dengan perbedaan kemiringan antara oprit dan lantai jembatan, dan kurva hubungan antara retak lantai jembatan dengan panjang oprit. Penafsiran hubungan/ korelasi antara dua variabel, digunakan analisa regresi linier, dengan formula: $\mathrm{Y}=$ $\mathrm{aX}+\mathrm{b}$.

Dimana:

$\mathrm{Y}=$ variabel dependen atau variabel terikat

$\mathrm{X}=$ variabel independen atau variabel bebas

$\mathrm{b}=$ konstanta (nilai $\mathrm{b}$ akan $=\mathrm{Y}$, jika $\mathrm{X}=0$ )

$\mathrm{a}=$ koef. regresi (nilai peningkatan /penurunan)

Jadi harga a merupakan fungsi dari koefisien korelasi. Bila koefisien korelasi tinggi, maka harga a juga akan besar, sebaliknya bila koefisien korelasi rendah maka harga a juga rendah (kecil). Nilainilai a dan b dapat dihitung dengan menggunakan formula sebagai berikut:

$\mathrm{a}=\frac{\mathrm{n}\left(\sum \mathrm{xy}\right)-\left(\sum x\right) \cdot\left(\sum y\right)}{n\left(\sum x^{2}\right)-\left(\sum x\right)^{2}} \quad b=\frac{\sum y-a \cdot\left(\sum x\right)}{n}$

\subsection{Metode Penarikan Kesimpulan}

Penarikan kesimpulan dilakukan dengan menarik garis regresi linier. Jika hasilnya positif atau negatif, maka panjang dan kemiringan oprit memepengaruhi kerusakan lantai jembatan diawal bentang, dan jika hasilnya zero (0), maka kondisi oprit tidak mempengaruhi kerusakan lantai jembatan diawal bentang. Untuk mengetahui seberapa besar pengaruh kondisi oprit terhadap kerusakan lantai jembatan diawal bentang, digunakan pendekatan Koefisien Determinasi $\left(\mathbf{R}^{2}\right)$. Nilai $\mathrm{R}^{2}$ diperoleh dari rumus berikut:

$R^{2}=1-\frac{\sum(\mathrm{Yr}-\mathrm{Y})^{2}}{\sum(\mathrm{Y}-\overline{\mathrm{Y}})^{2}}$

Dimana:

$\mathrm{Yr}=$ yang diperoleh dari persamaan garis regresi.

$\bar{Y}=$ Rata rata variabel tak bebas.

Penafsiran kuat dan tidaknya pengaruh kondisi oprit terhadap kerusakan lantai jembatan, didasarkan kepada nilai koefisien korelasi (R). Nilai koefisien korelasi (R). Diacu dari makalah yang disampaikan oleh: Jonathan Sarwono , dalam journal yang berjudul "PROSEDUR-PROSEDUR POPULER STATISTIK UNTUK MEMPERMUDAH RISET SKRIPSI “, dengan interpretasi sbb:

\begin{tabular}{|l|l|l|}
\hline N0 & Koefisien korelasi (R) & interpretasi \\
\hline 1 & 0 & Tidak ada korelasi \\
\hline 2 & $>0-0,25$ & Korelasi sangat lemah \\
\hline 3 & $>0,25-0,5$ & Korelasi cukup \\
\hline 4 & $>0,5-0,75$ & Korelasi kuat \\
\hline 5 & $>0,75-0,99$ & Korelasi sangat kuat \\
\hline 6 & 1 & Korelasi sempurna \\
\hline
\end{tabular}

Tabel 1. Interpretasi nilai koefien korelasi (R).

Nilai koefisien korelasi (R) diperoleh dengan meng-akarkuadrat-kan nilai Koefisien Determinasi $\left(\mathrm{R}^{2}\right)$ :

$$
R=\sqrt[2]{R^{2}}
$$

\subsection{Diagram Alir Penelitian}

Urutan kegiatan penelitian mengikuti tahapan tahapan yang dituangkan dalam diagram alir dibawah: 


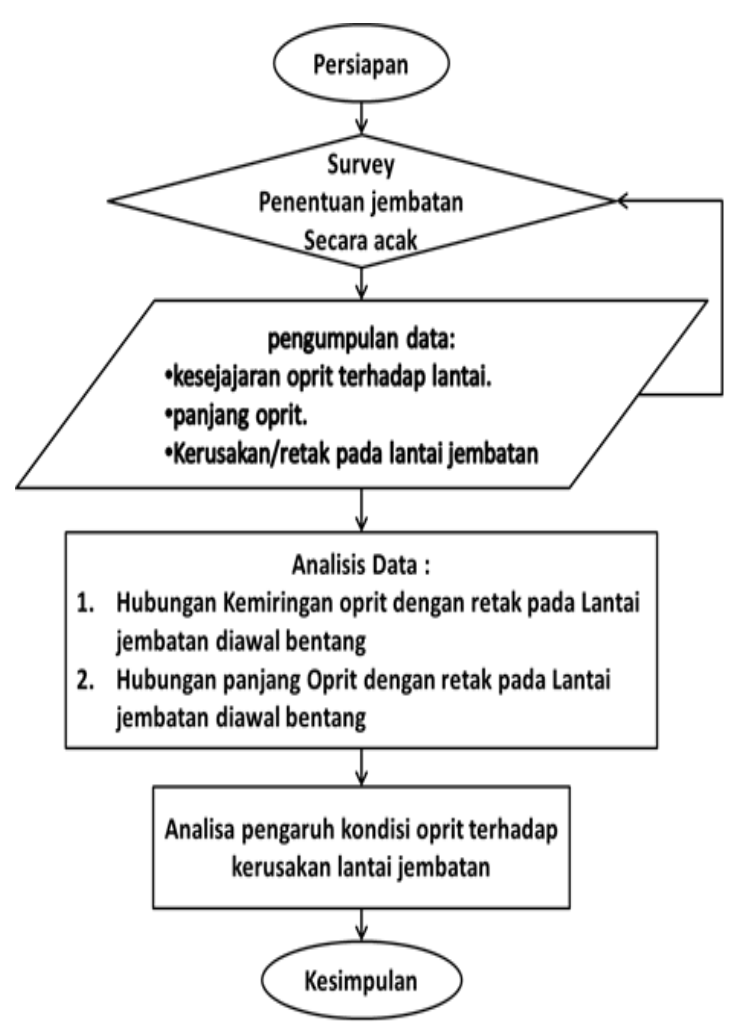

Gambar 5. Bagan alir kegiatan penelitian

\section{HASIL DAN PEMBAHASAN}

4.1 Lokasi obyek penelitian

Lokasi obyek penelitian diambil di daerah Depok dan Bogor. Jumlah jembatan yang disurvey di daerah Bogor sebanyak 14 buah, dan jumlah jembatan yang disurvey di daerah Depok sebanyak 4 buah.

\subsection{Kegiatan Pengumpulan data}

Dokumentasi kegiatan pengumpulan data

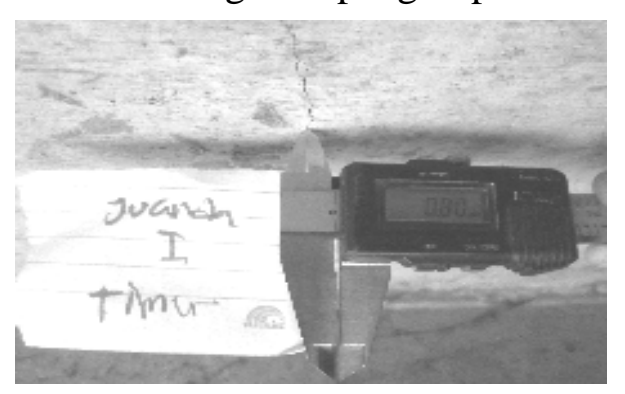

Gambar 6. Pengukuran lebar retak

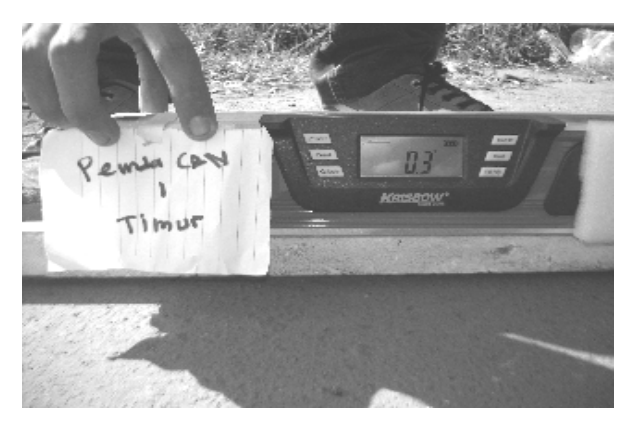

Gambar 7. Pengukuran kelandaian oprit

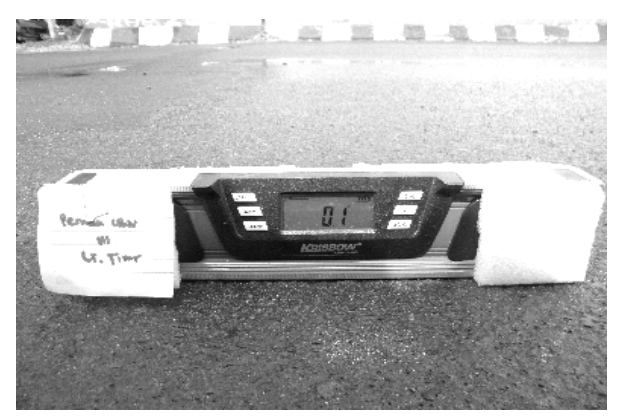

Gambar 8. Pengukuran kelandaian lantai jembatan

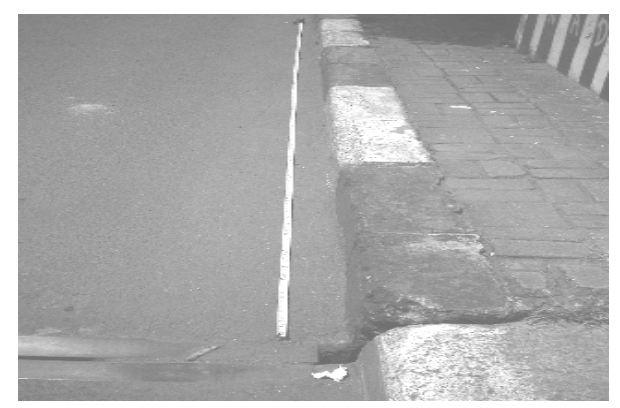

Gambar 9. Pengukuran panjang oprit

Data Pengukuran Lebar Retak, kelandaian oprit, kelandaian lantai jembatan dan panjang oprit disajikan pada tabel analisa data.

\subsection{Analisa Pengaruh Kondisi Lantai Injak Terhadap Kerusakan Lantai Jembatan}

Data hasil pengukuran sudut permukaan lantai injak dan sudut kemiringan lantai jembatan dengan Lebar retak lantai jembatan awal bentang. 


\begin{tabular}{|c|c|c|c|c|c|c|c|c|c|c|c|}
\hline \multirow{2}{*}{ No } & \multirow{2}{*}{ Nama Jembatan } & \multicolumn{2}{|c|}{$\begin{array}{l}\text { pengukuran } \\
\text { sudut } \\
\text { permukaan } \\
\end{array}$} & \multirow{2}{*}{$\begin{array}{l}\text { Perbe } \\
\text { daan } \\
\left(\ldots{ }^{\circ}\right)\end{array}$} & \multirow{2}{*}{$\begin{array}{l}\text { Lebar } \\
\text { Retak } \\
(\mathrm{mm})\end{array}$} & \multirow{2}{*}{ No } & \multirow{2}{*}{ Nama Jembatan } & \multicolumn{2}{|c|}{\begin{tabular}{|l|} 
pengukuran \\
sudut \\
permukaan
\end{tabular}} & \multirow{2}{*}{$\begin{array}{l}\text { Perbe } \\
\text { daan } \\
\left(\ldots{ }^{\circ}\right)\end{array}$} & \multirow{2}{*}{$\begin{array}{l}\text { Lebar } \\
\text { Retak } \\
(\mathrm{mm})\end{array}$} \\
\hline & & $\begin{array}{l}\text { Lantai } \\
\text { injak }\end{array}$ & $\begin{array}{c}\text { Lantai } \\
\text { Jemb. }\end{array}$ & & & & & $\begin{array}{l}\text { Lantai } \\
\text { injak }\end{array}$ & $\begin{array}{c}\text { Lantai } \\
\text { Jemb. }\end{array}$ & & \\
\hline 1 & Jb.Pmda Cbn I Tmr. & 0,3 & 0,1 & 0,20 & 0,30 & 16 & Jb. Cikeas III Brt & 1,7 & 0,3 & 1,40 & 0,63 \\
\hline 2 & Jb. Pmda Cbn 2 Tmr & 0 & 0,6 & 0,60 & 1,61 & 17 & Jb. Cikeas IV Brt & 1,1 & 0 & 1,10 & 0,00 \\
\hline 3 & Jb. Pmda Cbn 2 Brt & 0,2 & 0,4 & 0,20 & 0,00 & 18 & Jb. Kali Sunter I Tmr & 0 & 1,1 & 1,10 & 0,38 \\
\hline 4 & Jb.Pmda Cbn III Tmr & 0,5 & 0,1 & 0,40 & 0,58 & 19 & Jb. Kali Sunter I Brt & 0 & 0,8 & 0,80 & 1,04 \\
\hline 5 & Jb.Pmda Cbn IV Tmr & 2,1 & 0,5 & 1,60 & 0,67 & 20 & Jb. Kali Sunter 2 Tmr & 0,4 & 0,1 & 0,30 & 0,00 \\
\hline 6 & Jb. Pmda Cbn IV Brt & 1,1 & 0,2 & 0,90 & 0,92 & 21 & Jb. Kali Sunter 2 Brt & 0,1 & 0,4 & 0,30 & 0,86 \\
\hline 7 & Jb. Ank Cikeas I Tmr & 0,5 & 0,7 & 0,20 & 0,24 & 22 & Jb. Kota Wisata Tmr & 0,3 & 0 & 0,30 & 0,00 \\
\hline 8 & Jb. Ank Cikeas I Brt & 2,1 & 0,7 & 1,40 & 0,58 & 23 & Jb. Kota Wisata Brt & 0,4 & 0,3 & 0,10 & 0,00 \\
\hline 9 & Jb. Ank cikeas II Tmr & 1,7 & 0,2 & 1,50 & 1,44 & 24 & FO AR. hakim I Tmr & 2,8 & 2,8 & 0,00 & 0,00 \\
\hline 10 & Jb.Ank cikeas II Brt & 0,9 & 0,6 & 0,30 & 0,31 & 25 & FO AR .hakim I Brt & 2,8 & 2,7 & 0,10 & 0,00 \\
\hline 11 & Jb.Ank Cikeas III Tmr & 1,1 & 1,2 & 0,10 & 0,00 & 26 & FO AR. hakim II Tmr & 2,8 & 2,7 & 0,10 & 0,00 \\
\hline 12 & Jb. Ank Cikeas III Brt & 1,2 & 0,6 & 0,60 & 0,68 & 27 & FO AR. hakim II Brt & 3,7 & 2,6 & 1,10 & 0,00 \\
\hline 13 & Jb. Ank Cikeas IV Tmr & 3,2 & 0 & 3,20 & 3,00 & 28 & Jb. juanda I Tmr & 1,1 & 0,5 & 0,60 & 0,80 \\
\hline 14 & Jb. Cikeas I Tmr & 0,2 & 0 & 0,20 & 0,60 & 29 & Jb. juanda II Tmr & 0,3 & 0,3 & 0,00 & 0,20 \\
\hline 15 & Jb. Cikeas II Brt & 0,3 & 0,3 & 0,00 & 0,13 & & & & & & \\
\hline
\end{tabular}

Tabel 2. Data pengukuran kelandaian lantai injak ,lantai jembatan dan lebar retak lantai jembatan awal bentang

Sumber: data TA Tubagus dengan pembimbing Andi Indianto

Perhitungan Garis Regresi.

Persamaan Garis Regresi linier yang digunakan adalah: $\mathrm{Y}=\mathrm{a} \mathrm{X}+\mathrm{b}$.

Dimana : $\quad \mathrm{a}=\frac{\mathrm{n}\left(\sum \mathrm{xy}\right)-\left(\sum x\right) \cdot\left(\sum y\right)}{n\left(\sum x^{2}\right)-\left(\sum x\right)^{2}} \quad b=\frac{\sum y-a \cdot\left(\sum x\right)}{n}$

\begin{tabular}{|c|c|c|c|c|c|c|c|c|c|c|c|}
\hline $\mathrm{NO}$ & $\mathrm{X}$ & $\mathrm{Y}$ & $\mathrm{XY}$ & $\mathrm{X}^{2}$ & $\mathrm{Y}^{2}$ & $\mathrm{NO}$ & $\mathrm{X}$ & $\mathrm{Y}$ & $\mathrm{XY}$ & $\mathrm{X}^{2}$ & $\mathrm{Y}^{2}$ \\
\hline 1 & 4 & 0,68 & 2,72 & 16,00 & 0,46 & 11 & 5,05 & 0,2 & 1,01 & 25,50 & 0,04 \\
\hline 2 & 0,35 & 1,44 & 0,50 & 0,12 & 2,07 & 12 & 3,1 & 0,67 & 2,08 & 9,61 & 0,45 \\
\hline 3 & 2,1 & 0,31 & 0,65 & 4,41 & 0,10 & 13 & 4,9 & 0 & 0,00 & 24,01 & 0,00 \\
\hline 4 & 3,4 & 0,24 & 0,82 & 11,56 & 0,06 & 14 & 5 & 0 & 0,00 & 25,00 & 0,00 \\
\hline 5 & 3,6 & 0,8 & 2,88 & 12,96 & 0,64 & 15 & 5,15 & 0 & 0,00 & 26,52 & 0,00 \\
\hline 6 & 3,76 & 0,58 & 2,18 & 14,14 & 0,34 & 16 & 4,8 & 0,38 & 1,82 & 23,04 & 0,14 \\
\hline 7 & 4,1 & 0,63 & 2,58 & 16,81 & 0,40 & 17 & 5,1 & 0 & 0,00 & 26,01 & 0,00 \\
\hline 8 & 4,2 & 0,6 & 2,52 & 17,64 & 0,36 & 18 & 5,12 & 0 & 0,00 & 26,21 & 0,00 \\
\hline 9 & 4,2 & 0,13 & 0,55 & 17,64 & 0,02 & 19 & 5,12 & 0 & 0,00 & 26,21 & 0,00 \\
\hline 10 & 3 & 0,3 & 0,90 & 9,00 & 0,09 & $\mathrm{n}=19$ & $\sum=76,05$ & $\sum=6,96$ & $\sum=21,21$ & $\sum=332,4$ & $\sum=5,16$ \\
\hline
\end{tabular}

$\left(\sum X\right) 2=5783,60$

Tabel 6. Data Perhitungan Garis Regresi.

$$
\begin{aligned}
& \mathrm{a}=\frac{\mathrm{n}\left(\sum \mathrm{xy}\right)-\left(\sum x\right) \cdot\left(\sum y\right)}{n\left(\sum x^{2}\right)-\left(\sum x\right)^{2}}=\frac{19(21,21)-(76,05) \cdot(6,96)}{19(332,40)-(5783,60)}=\frac{403,02-529,31}{6315,67-5783,60}=\frac{-126,2838}{532,0716}=-0,2373 \\
& b=\frac{\sum y-a \cdot\left(\sum x\right)}{n}=\frac{6,9600-(-0,2373) x 76,0500}{19}=\frac{6,9600-(-18,0466)}{19}=1,3161
\end{aligned}
$$

Persamaan garis regresi untuk analisa pengaruh panjang lantai injak terhadap kerusakan lantai jembatan awal bentang adalah : $\mathrm{Y}=-0,2373 \mathrm{X}+1,3161$

\section{Persamaan Koefisien Determinasi $\left(\mathrm{R}^{2}\right)$}

Dari Hasil persamaan garis Regresi : $\mathrm{Y}=-0,2373 \mathrm{X}+1,3161$, diperoleh nilai Yr. Yang selanjutnya nilai Yr digunakan untuk menghitung nilai Koefisien Determinasi $\left(\mathrm{R}^{2}\right)$ dengan menggunakan formula : $R^{2}=1-\frac{\sum(\mathrm{Yr}-\mathrm{Y})^{2}}{\sum(\mathrm{Y}-\overline{\mathrm{Y}})^{2}}$ 


\begin{tabular}{|c|c|c|c|c|c|c|c|c|c|c|c|c|c|c|c|}
\hline No & $\mathrm{X}$ & $\mathrm{Y}$ & $\mathrm{Y}_{\mathrm{r}}$ & $\left(\mathrm{Y}_{\mathrm{r}}-\mathrm{Y}\right)$ & $\left(\mathrm{Y}_{\mathrm{r}}-\mathrm{Y}\right)^{2}$ & $(\mathrm{Y}-\bar{Y})$ & $(\mathrm{Y}-\bar{Y})^{2}$ & $\mathrm{No}$ & $\mathrm{X}$ & $\mathrm{Y}$ & $\mathrm{Y}_{\mathrm{r}}$ & $\left(\mathrm{Y}_{\mathrm{r}}-\mathrm{Y}\right)$ & $\left(\mathrm{Y}_{\mathrm{r}}-\mathrm{Y}\right)^{2}$ & $(\mathrm{Y}-\bar{Y})$ & $(\mathrm{Y}-\bar{Y})^{2}$ \\
\hline 1 & 4,00 & 0,68 & 0,37 & $-0,31$ & 0,10 & 0,31 & 0,10 & 11 & 5,05 & 0,20 & 0,12 & $-0,08$ & 0,01 & $-0,17$ & 0,03 \\
\hline 2 & 0,35 & 1,44 & 1,23 & $-0,21$ & 0,04 & 1,07 & 1,15 & 12 & 3,10 & 0,67 & 0,58 & $-0,09$ & 0,01 & 0,30 & 0,09 \\
\hline 3 & 2,10 & 0,31 & 0,82 & 0,51 & 0,26 & $-0,06$ & 0,00 & 13 & 4,90 & 0,00 & 0,15 & 0,15 & 0,02 & $-0,37$ & 0,13 \\
\hline 4 & 3,40 & 0,24 & 0,51 & 0,27 & 0,07 & $-0,13$ & 0,02 & 14 & 5,00 & 0,00 & 0,13 & 0,13 & 0,02 & $-0,37$ & 0,13 \\
\hline 5 & 3,60 & 0,80 & 0,46 & $-0,34$ & 0,11 & 0,43 & 0,19 & 15 & 5,15 & 0,00 & 0,09 & 0,09 & 0,01 & $-0,37$ & 0,13 \\
\hline 6 & 3,76 & 0,58 & 0,42 & $-0,16$ & 0,02 & 0,21 & 0,05 & 16 & 4,80 & 0,38 & 0,18 & $-0,20$ & 0,04 & 0,01 & 0,00 \\
\hline 7 & 4,10 & 0,63 & 0,34 & $-0,29$ & 0,08 & 0,26 & 0,07 & 17 & 5,10 & 0,00 & 0,11 & 0,11 & 0,01 & $-0,37$ & 0,13 \\
\hline 8 & 4,20 & 0,60 & 0,32 & $-0,28$ & 0,08 & 0,23 & 0,05 & 18 & 5,12 & 0,00 & 0,10 & 0,10 & 0,01 & $-0,37$ & 0,13 \\
\hline 9 & 4,20 & 0,13 & 0,32 & 0,19 & 0,04 & $-0,24$ & 0,06 & 19 & 5,12 & 0,00 & 0,10 & 0,10 & 0,01 & $-0,37$ & 0,13 \\
\hline 10 & 3,00 & 0,30 & 0,60 & 0,30 & 0,09 & $-0,07$ & 0,00 & \multicolumn{1}{|c|}{ Rata - Rata } & 0,37 & Jumlah & 1,04 & Jumlah & 2,61 \\
\hline
\end{tabular}

Tabel 7. Data Persamaan Koefisien Determinasi $\left(\mathrm{R}^{2}\right)$

$$
R^{2}=1-\frac{\sum(\mathrm{Yr}-\mathrm{Y})^{2}}{\sum(\mathrm{Y}-\overline{\mathrm{Y}})^{2}}=1-\frac{1,04}{2,61}=1-0,40=0,60 \quad R=\sqrt[2]{R^{2}}=\sqrt[2]{0,60}=0,77
$$

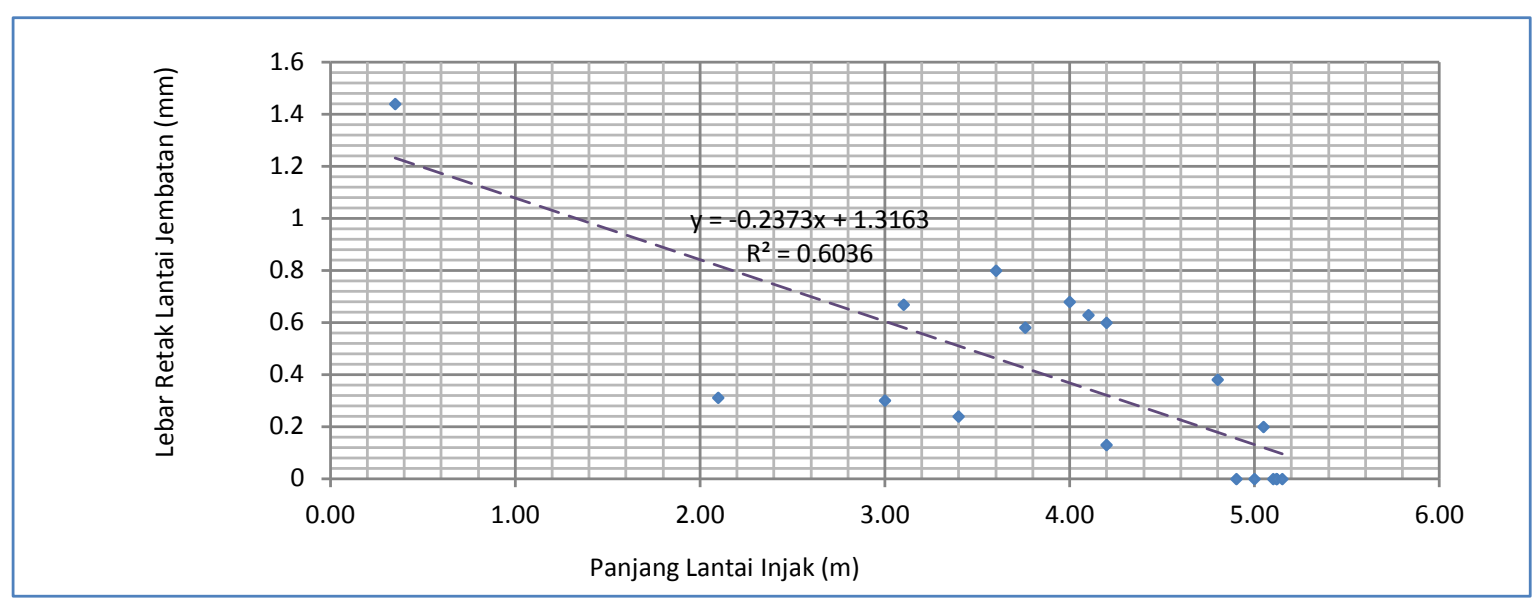

Gambar 11. : Grafik hubungan antara panjang lantai injak dengan lebar retak lantai jembatan

Penarikan Kesimpulan

Dari grafik korelasi dengan persamaan $\mathrm{Y}=$ $-0,2373 X+1,3161$, dapat di simpulkan bahwa jika lantai injak semakin panjang, maka kerusakan lantai jembatan diawal bentang semakin kecil.

Besarnya pengaruh panjang lantai injak terhadap kerusakan lantai jembatan diawal bentang dinyatakan dalam koefisien korelasi $(\mathrm{R})$ sebesar $=0,77$. Berdasarkan Tabel 1 (Interpretasi nilai koefien korelasi $\mathrm{R}=0,77$ adalah Korelasi sangat kuat ), Sehingga dapat di simpulkan bahwa panjang lantai injak, sangat mempengaruhi kerusakan lantai jembatan diawal bentang.

\section{KESIMPULAN}

a. Perbedaan kemiringan antara lantai jembatan awal bentang dengan kemiringan permukaan lantai injak berpengaruh kuat terhadap kerusakan lantai jembatan diawal bentang, dengan nilai koefisien korelasi(R)sebesar 0,75.

b. Semakin besar perbedaan kemiringan antara lantai jembatan diawal bentang dengan kemiringan permukaam lantai injak, maka kerusakan lantai jembatan diawal bentang semakin besar, ditunjukkan oleh persamaan garis regresi $\mathrm{Y}=0,6972 \mathrm{X}+0,0666$.

c. Panjang lantai injak, sangat mempengaruhi kerusakan lantai jembatan diawal bentang, dengan nilai koefien korelasi (R) sebesar 0,77.

d. Jika lantai injak semakin panjang, maka kerusakan lantai jembatan diawal bentang semakin kecil, ditunjukkan oleh persamaan garis regresi $\mathrm{Y}=-0,2373 \mathrm{X}$ $+1,3161$.

e. Dari ke empat narasi diatas dapat disimpulkan bahwa kelandaian dan panjang lantai injak sangat 
mempengaruhi tingkat kerusakan lantai jembatan diawal bentang,

f. penyebab rusaknya lantai jembatan diawal bentang adalah tidak sejajarnya lantai injak dengan lantai jembatan diawal bentang dan kurang panjangnya lantai oprit.

\section{DAFTAR PUSTAKA}

[1] Kementerian PU, 2010, "Panduan Penanganan Preservasi Jembatan" Jakarta : Direktorat Jenderal Bina Marga.

[2] Kementerian PU. 2010. Perencanaan Teknik Jembatan ", Jakarta : Direktorat Jenderal Bina Marga

[3] Kementerian PU. 2011. "Pedoman Pemeriksaan Jembatan", Jakarta: Direktorat Jenderal Bina Marga

[4] Muh. Subhan. 2007. "Jurnal Identifikasi Sebab-sebab kerusakan oprit jembatan dan alternatif penanganannya (Studi Kasus : Jembatan Nambo - Bungukoto Kota Kendari)". Yogyakarta: UGM

[5] Sarwono, Jonathan. 2006. "Analisis Data Penelitian Menggunakan SPSS". Yogyakarta: Andi Offset.

[6] Sugiyono, Prof.Dr. 2012. "Statistika Untuk Penelitian". Bandung: Alfabeta. 
Andi Indianto dan Setiyadi, Pengaruh Panjang Dan Kesejajaran... 